\title{
REMOVAL OF PHOSPHATE BY ION EXCHANGE RESIN: KINETIC AND THERMODYNAMIC STUDY
}

\author{
R. Drissi*and C. Mouats \\ Department of Chemistry, University of Frères Mentouri, Constantine 2500, Algeria. \\ *E-mail: rima_drissi@yahoo.fr
}

\begin{abstract}
The removal of phosphate ions by a weakly basic anion exchanger Amberlite IRA-67 resin was investigated. Equilibrium data were best described by Freundlich isotherm and second-order kinetic equation. Thermodynamic parameters reveal that adsorption is spontaneous and a heat releasing process.
\end{abstract}

Keywords: Adsorption, Amberlite IRA-67, Freundlich, Langmuir, Resin

(C) RASĀYAN. All rights reserved

\section{INTRODUCTION}

Phosphorus is an omnipresent element in the environment. It exists naturally in sediments, plants and the human body, but the irrational use of detergents and fertilizers lead to the problem of asphyxiation of the aquatic environment known as eutrophication. Algeria has recommended a standard concentration of $2 \mathrm{mg}$ of phosphorus/L as a discharge limit for industrial liquid effluents ${ }^{1}$ while the US Environmental Protection Agency (USEPA) has set a limit of $0.1 \mathrm{mg}$ of phosphate/L for rivers and streams ${ }^{2}$. The most common methods to fight against this type of pollution are chemical ${ }^{3}$ and biological ${ }^{4}$ methods. These methods require significant amounts of reagents or chemical products, high maintenance costs plus the requirement of specific conditions such as $\mathrm{pH}$, temperature, and dissolved oxygen. Resins are able to capture and eliminate other ions in aqueous solutions until reaching the point of saturation. When the resin is exhausted it can be regenerated by simple washing with a solution containing the same anion or cation which increases the scope of the use of this material in different treatment fields. This work was aimed to investigate the applicability of a weakly basic anion resin Amberlite IRA-67 for the removal of phosphate from synthetic solutions at different $\mathrm{pH}$, absorbent dosage, contact time, and temperature.

\section{Material and Methods}

\section{EXPERIMENTAL}

\section{Adsorbent}

Commercial weak base anion exchange resin; Amberlite IRA-67 (purchased from BDH Chemicals, USA) was used to remove phosphate ions from aqueous solutions. Amberlite IRA-67 is a microporous acrylic gel resin containing only tertiary amine functional groups with total exchange capacity of $5.6 \mathrm{meq} / \mathrm{g}$.

\section{Adsorbate}

A stock of phosphate solution was prepared by dissolving an accurate quantity of potassium phosphate monobasic $\mathrm{KH}_{2} \mathrm{PO}_{4}$ (sigma-Aldrich $\geq 98.0 \%$ ) in distilled water. Required concentrations were prepared by appropriate dilution of the freshly prepared stock solution.

\section{Adsorption Experiment}

Batch experiments were carried out to investigate the effect of different parameters on phosphate ions removal. All adsorption experiments were carried out at the room temperature.

Rasayan J. Chem., 11(3), 1126 - 1132(2018)

http://dx.doi.org/10.31788/RJC.2018.1132081

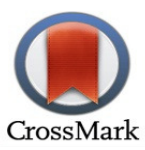


RASĀYAN $J$. Chem.

Vol. 11 | No. 3 |1126 - 1132 | July - September | 2018

The effect of $\mathrm{pH}$ on the adsorption was examined by mixing $0.125 \mathrm{~g}$ of resin with $25 \mathrm{~mL}$ of phosphate solution $(100 \mathrm{~mol} / \mathrm{L})$ at different $\mathrm{pH}$ range (2-10) by adding drops of $\mathrm{HCl}$ or $\mathrm{NaOH}(1 \mathrm{M})$ and using a HANNA $211 \mathrm{pH}$-meter. Isotherm experiments were carried out by agitating $0.125 \mathrm{~g}$ of resin with $25 \mathrm{~mL}$ of phosphate solution of different initial concentrations ranging from 100 to $1000 \mathrm{mg} / \mathrm{L}$ at a constant speed of $120 \mathrm{rpm}$ for 24 hours. The kinetics study was carried out by agitating $50 \mathrm{ml}$ flasks containing $0.125 \mathrm{~g}$ of resin and $25 \mathrm{~mL}$ of phosphate solutions $(100 \mathrm{~mol} / \mathrm{L})$. The mixture was shaken at $120 \mathrm{rpm}$. The flasks were removed at a predetermined time from the shaker and the samples solutions were filtered and analyzed. Temperature effect was studied at 20,30 and $40^{\circ} \mathrm{C} .0 .125 \mathrm{mg}$ of resin and a phosphate solution of an initial concentration of $100 \mathrm{mg} / \mathrm{L}$ were mixed and placed in a constant temperature bath for 24 hours to ensure the adsorption process reach the equilibrium stage. Concentrations of phosphate ions at equilibrium were determined by Molybdenum blue method ${ }^{5}$ using a double beam uv-vis spectrophotometer (OPTIZEN 2120 $U V$ ) and employing $1 \mathrm{~cm}$ quartz cuvette at a wavelength of $700 \mathrm{~nm}$. The adsorbed amount of phosphate ions at the equilibrium in $(\mathrm{mg} / \mathrm{g})$ was calculated by the following equation:

$$
q_{e}=\frac{\left(C_{0}-C_{e}\right) * V}{m}
$$

Where $\mathrm{C}_{0}$ is the initial concentration, $\mathrm{C}_{\mathrm{e}}$ is the equilibrium concentration, $\mathrm{V}$ is the solution volume (L), and $\mathrm{m}$ is the mass of adsorbent $(\mathrm{g})$.

\section{Equilibrium Adsorption Isotherm Models}

Langmuir and Freundlich isotherms models were used in this study to describe the sorption experimental data.

Langmuir isotherm is based on the assumption that uptake occurs on a homogenous surface by monolayer sorption with-out interaction between adsorbed molecules ${ }^{6}$. Langmuir isotherm is represented by the following eqn. $(2)^{7}$ :

$$
q_{e}=\frac{q_{\max } k_{L} C_{e}}{1+k_{L} C_{e}}
$$

The linear form of this model is as eqn. (3):

$$
\frac{C_{e}}{q_{e}}=\frac{1}{q_{\max } k_{L}}+\frac{C_{e}}{q_{\max }}
$$

$\mathrm{C}_{\mathrm{e}}$ is the equilibrium concentration in $(\mathrm{mg} / \mathrm{L}), \mathrm{q}_{\mathrm{e}}$ is the adsorbed amount at equilibrium per unit of adsorbent in $(\mathrm{mg} / \mathrm{g}), \mathrm{q}_{\max }$ is the maximum adsorption capacity in $(\mathrm{mg} / \mathrm{g})$, and $\mathrm{K}_{\mathrm{L}}$ is the Langmuir constant.

Freundlich isotherm is assuming that the adsorption process takes place on a heterogeneous surface ${ }^{8}$. Freundlich isotherm is represented by eqn. (4) ${ }^{9}$ :

$$
q_{e}=K_{F} C_{e}^{n}
$$

The linear form of this model is as the follow eqn. (5):

$$
\ln q_{e}=\ln K_{F}+n \ln C_{e}
$$

Freundlich constants $\mathrm{n}$ and $\mathrm{k}$ were determined graphically from the slope and intercept of the linear plot of $\operatorname{lnq}_{\mathrm{e}}$ versus $\ln \mathrm{C}_{\mathrm{e}}$.

\section{Adsorption Kinetics}

The pseudo-first-order and pseudo-second-order model were applied to study the kinetics of phosphate adsorption.

\section{Pseudo-First Order Model}

The pseudo-first order kinetic model is expressed by the eqn. $(6)^{10}$ :

$$
\ln \left(q_{e}-q_{t}\right)=\ln q_{e}-K_{1} t
$$


RASĀYAN J. Chem.

Vol. 11 | No. 3 |1126 - 1132 | July - September | 2018

$\mathrm{q}_{\mathrm{e}}$ and $\mathrm{q}_{\mathrm{t}}$ are the amount of the adsorbed phosphate $(\mathrm{mg} / \mathrm{g})$ at equilibrium and at time $\mathrm{t}$ respectively while $\mathrm{K}_{1}$ is the rate constant $\left(\mathrm{min}^{-1}\right) . \mathrm{K}_{1}$ can be determined from the slope of the linear plot $\ln \left(\mathrm{q}_{\mathrm{e}}-\mathrm{q}_{\mathrm{t}}\right)$ versus $\mathrm{t}$.

\section{Pseudo-Second Order Model}

The pseudo-second-order kinetic model is expressed by eqn. $(7)^{11}$ :

$$
\frac{t}{q_{t}}=\frac{1}{k_{2} q_{e}{ }^{2}}+\left(\frac{1}{q_{e}}\right) t
$$

$\mathrm{q}_{\mathrm{e}}$ and $\mathrm{q}_{\mathrm{t}}$ are the amount of the adsorbed phosphate $(\mathrm{mg} / \mathrm{g})$ at equilibrium and at time $\mathrm{t}$ respectively, while $\mathrm{k}_{2}$ is the rate constant (g/mg.min). $\mathrm{q}_{\mathrm{e}}$ and $\mathrm{k}_{2}$ can be determined from the plot of $\frac{t}{q_{t}}$ versus $\mathrm{t}$.

\section{pH Effect}

\section{RESULTS AND DISCUSSION}

Figure-1 shows the percentage of phosphate ions removed as a function of $\mathrm{pH}$ value. $\mathrm{pH}$ plays a significant role in removal efficiency ${ }^{12}$, phosphate can exist in the form of $\mathrm{H}_{3} \mathrm{PO}_{4}$ at $\mathrm{pH}$ below $2, \mathrm{H}_{2} \mathrm{PO}_{4}^{-}$is the predominant species for $\mathrm{pH}$ between 2 and $7 . \mathrm{HPO}_{4}{ }^{2-}$ is the dominant species for $\mathrm{pH}$ between 7 and 12 , for $\mathrm{pH}$ higher than 12, the fully dominant species is $\mathrm{PO}_{4}^{-3}$. According to (Fig.-1), the adsorption capacity decreased from 98.67 to $88.23 \%$ as the $\mathrm{pH}$ increases from 2 to 10 . This result indicates that the adsorption process was $\mathrm{pH}$-dependent and the sorption capacity of Amberlite IRA-67 decreased significantly at high $\mathrm{pH}$ values since most of the amine groups on the resin had converted into the base form and lost the ability of anion exchange ${ }^{13}$. Also, it may be due to the competition between phosphate and hydroxyl ions at high $\mathrm{pH}$ values. A similar result was reported by Ying et $\mathrm{al}^{14}$.

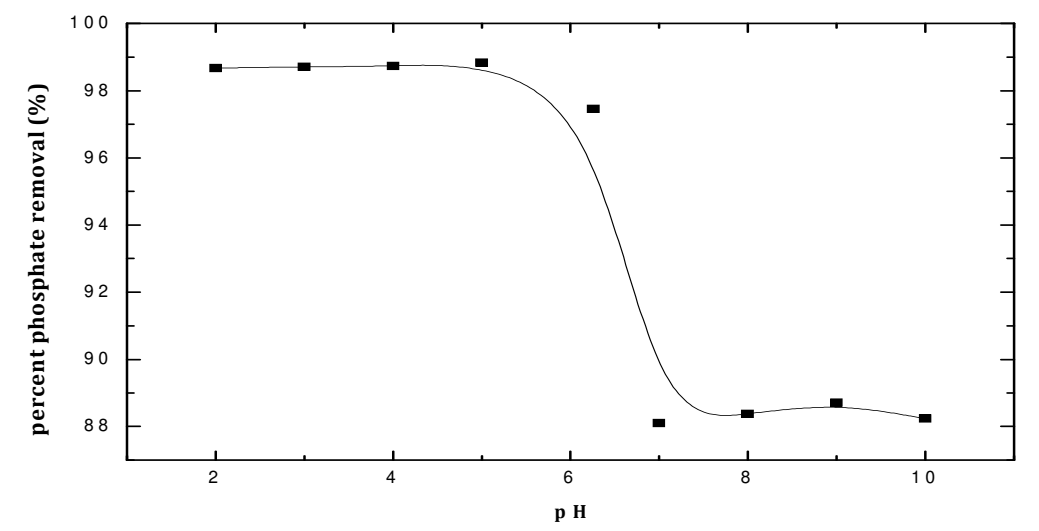

\section{Adsorption Isotherms}

Fig.-1: pH Effect on Phosphate Removal.

Figure-2 shows that the adsorption capacity of the resin increases from 19.01 to $78.45 \mathrm{mg} / \mathrm{gwith}$ the increase of the initial concentration from $100 \mathrm{mg} / \mathrm{L}$ to $500 \mathrm{mg} / \mathrm{L}$. When the concentrations are low, the arrival of the phosphate ions to the surface of the material is done quickly and the exchange between ions will be very easy and thus the exchange capacity of the resin will grow. On the other hand, at high concentrations, the formation of ion aggregation prevents the penetration of the phosphate ions into the particles of the resin and the exchange process becomes slow ${ }^{15}$, this phenomenon can be translated by the appearance of a saturation plateau (Fig.-2), which indicates any further addition of phosphate ions will be meaningless. The maximum adsorbed amount was $120.63 \mathrm{mg} / \mathrm{g}$, this quantity is higher compared to the quantity eliminated by other resins like macroporous resin XDA-7 $(20.9 \mathrm{mg} / \mathrm{g})^{16}$ and a strong base resin Dowex 21KXLT (39 $\mathrm{mg} / \mathrm{g})^{17}$. Table-1 summarized adsorption maximum capacity of some other adsorbents used for phosphate removal from aqueous solution. Langmuir (Fig-3) and Freundlich (Fig-4) isotherm parameters were summarized in Table-2. The correlation coefficient $\left(\mathrm{R}^{2}\right)$ values show that the adsorption process follows the Freundlich model which indicates the surface of the resin is more heterogeneous during the phosphate adsorption ${ }^{18}$. 
RASĀYAN J. Chem.

Vol. 11 | No. 3 |1126 - 1132 | July - September | 2018

Table-1: Adsorption Maximum Capacity (mg/g) of Different Adsorbents.

\begin{tabular}{c|c}
\hline Adsorbent & Adsorption Maximum Capacity (mg/g) \\
\hline XDA-7 Resin $^{16}$ & 20.9 \\
\hline Dowex 21K XLT $^{17}$ & 39 \\
\hline Aleppo Pine Adsorbent $^{19}$ & 0.889 \\
\hline Dolomite Mineral $^{20}$ & 4.76 \\
\hline Iron Oxide/Activated Carbon $^{21}$ & 98.39 \\
\hline Activated Carbon & \\
\hline Fly Ash $^{22}$ & 78.90 \\
\hline Amberlite IRA-67 & 9.15 \\
\hline
\end{tabular}

Table-2: Langmuir and Freundlich Isotherm Parameters of Phosphate Adsorption.

\begin{tabular}{c|c|c|c|c|c}
\hline \multicolumn{3}{c|}{ Langmuir isotherm model } & \multicolumn{3}{c}{ Freundlich isotherm model } \\
\hline $\mathrm{K}_{\mathrm{L}}(\mathrm{L} / \mathrm{mg})$ & $\mathrm{q}_{\max }(\mathrm{mg} / \mathrm{g})$ & $\mathrm{R}^{2}$ & $\mathrm{~K}_{\mathrm{F}}$ & $\mathrm{n}$ & $\mathrm{R}^{2}$ \\
\hline 0.04 & 120.63 & 0.95314 & 14.15 & 0.36 & 0.98899 \\
\hline
\end{tabular}

\section{Kinetic Study}

The experimental data indicate that equilibrium was reached after 30 minutes of contact, which shows a great affinity between the phosphate ions and the Amberlite IRA-67 resin (Fig.-5). According to the correlation coefficient values shown in Table-3, the experimental data are best described by the secondorder model (Fig.-7) rather than the first-order model (Fig.-6) with correlation coefficients above 0.99.In adsorption processes, a pseudo-second-order model is generally interpreted to mean that the mechanism of the process is mainly controlled by chemical bonding or chemisorptions ${ }^{23}$. A similar result was reported by Xiaoyan et $\mathrm{al}^{24}$, Jung et $\mathrm{al}^{25}$ and $\mathrm{Akbar}$ et $\mathrm{al}^{26}$.

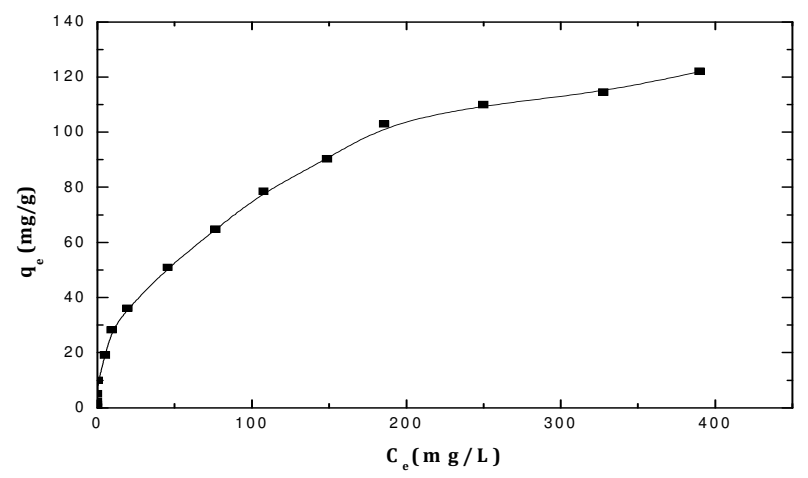

Fig.- 2: Concentration Effect on Phosphate Removal.

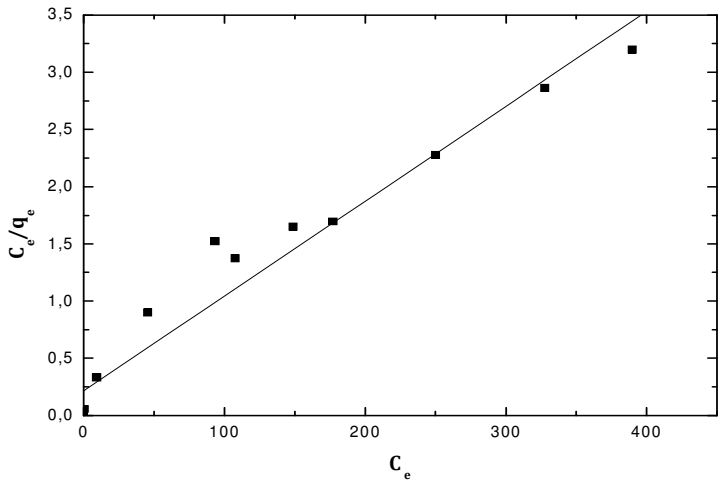

Fig.-3: Langmuir Isotherm Model

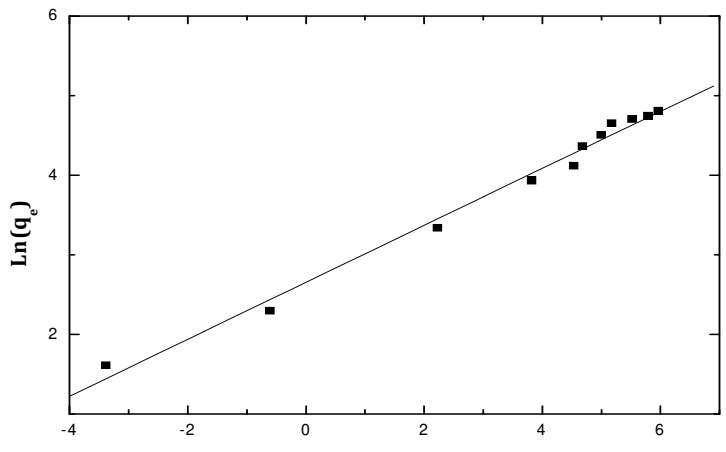

Fig.-4 :Freundlich Isotherm Model 
RASĀYAN J. Chem.

Vol. 11 | No. 3 |1126 - 1132 | July - September | 2018

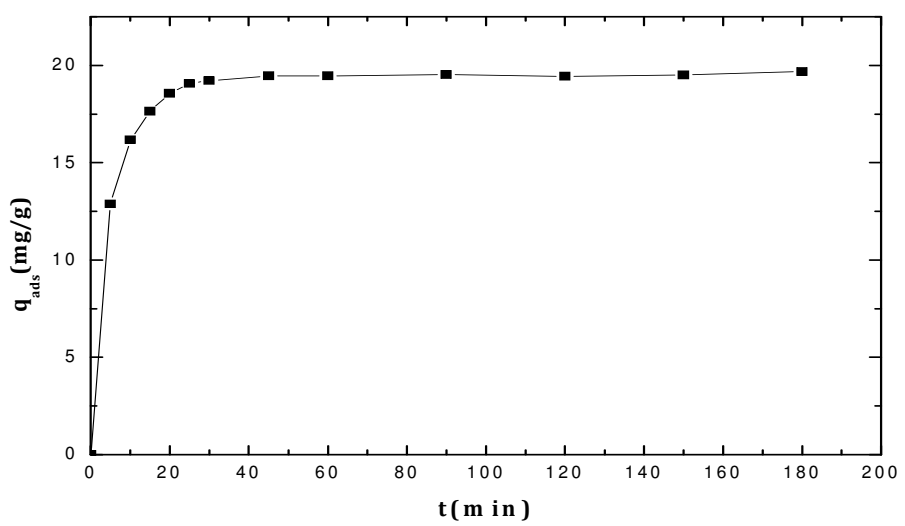

Fig.-5 : Removal of Phosphate as a Function of Equilibrium Time

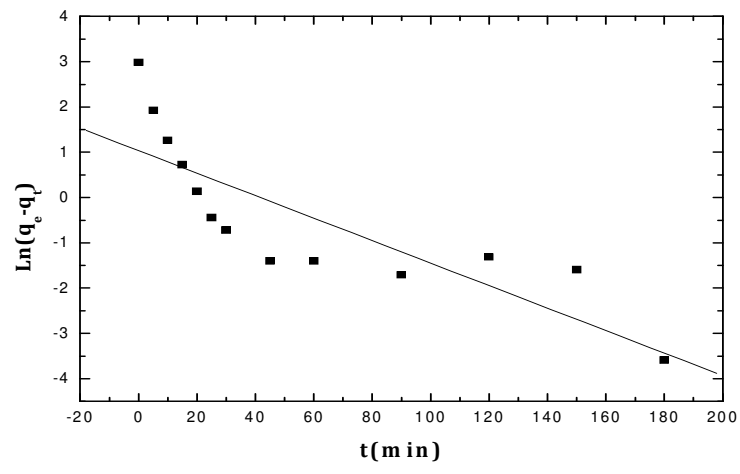

Fig.-6 :Pseudo-First Order Kinetics of Phosphate Adsorption

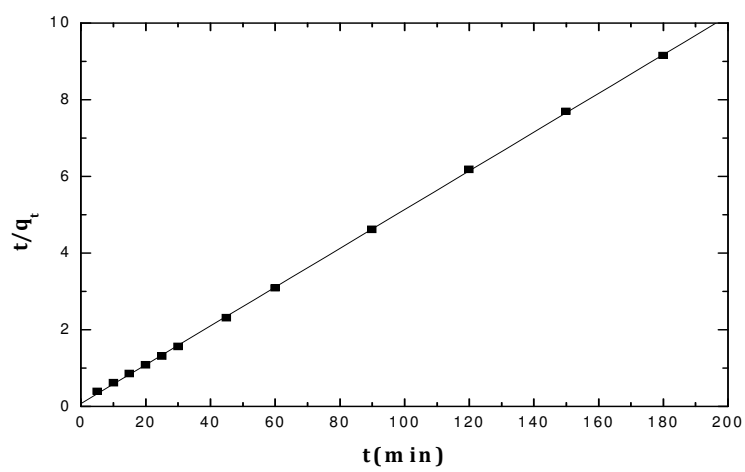

Fig.-7 :Pseudo Second Order Kinetics of Phosphate Adsorption

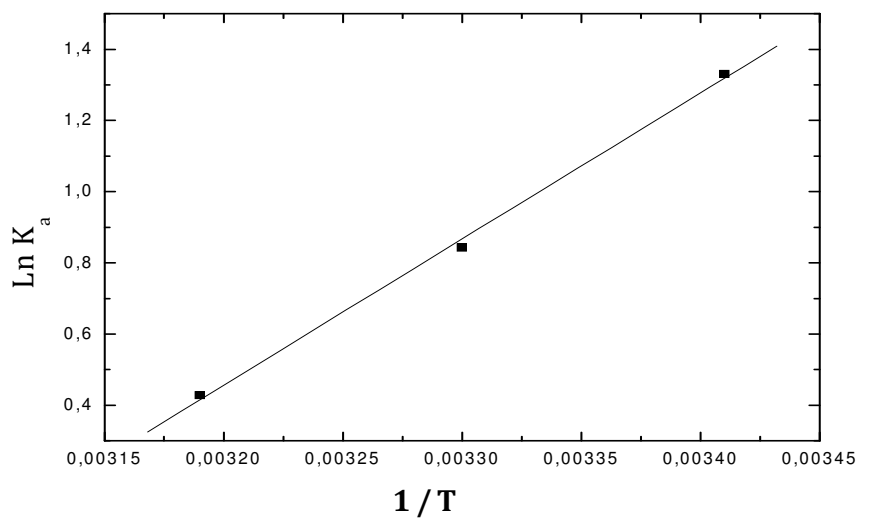

Fig.-8: Plot of lnKa Versus 1/T

Table-3: Kinetic Parameters for Sorption of Phosphate on Amberlite IRA-67.

\begin{tabular}{c|c|c|c}
\hline \multicolumn{2}{c|}{ Pseudo -First Order } & \multicolumn{2}{c}{ Pseudo-Second-Order } \\
\hline $\mathrm{k}_{\mathrm{t}}\left(\mathrm{min}^{-1}\right)$ & $\mathrm{R}^{2}$ & $\mathrm{k}_{\mathrm{t}}(\mathrm{g} / \mathrm{mg} \cdot \mathrm{min})$ & $\mathrm{R}^{2}$ \\
\hline 0.032 & 0.69334 & 0.025 & 0.99988 \\
\hline
\end{tabular}

\section{Thermodynamic Parameters}

Temperature effect on adsorption capacity was studied at 20,30 and $40^{\circ} \mathrm{C}$. Thermodynamic parameters such as Gibb's free energy, enthalpy change, and entropy change were calculated using the following equations: 
RASĀYAN J. Chem.

Vol. 11 | No. 3 |1126 - 1132 | July - September | 2018

$\Delta G^{\circ}=-\mathrm{RT} \ln \mathrm{K}_{\mathrm{a}}$

$\Delta G^{\circ}=\Delta H^{\circ}-T \Delta S^{\circ}$

$\ln \mathrm{K}_{\mathrm{a}}=\frac{\Delta S^{\circ}}{R}-\frac{\Delta H^{\circ}}{R T}$

Where $R$ is universal gas constant $(8.314 \mathrm{~J} / \mathrm{mol} . \mathrm{K})$, $\mathrm{T}$ is the temperature in Kelvin and $\mathrm{K}_{\mathrm{a}}$ is the equilibrium constant of adsorption, can be calculated from eqn. (11):

$$
\mathrm{K}_{\mathrm{a}}=\frac{C_{a d s}}{C_{e}}
$$

$\mathrm{C}_{\mathrm{ads}}$ is the adsorbed amount and $\mathrm{C}_{\mathrm{e}}$ is the equilibrium concentration. The plot of $\ln \mathrm{K}_{\mathrm{a}}$ versus $1 / \mathrm{T}$ allows us to obtain $\Delta \mathrm{H}^{\circ}$ and $\Delta \mathrm{S}^{\circ}$ values. Thermodynamic parameters are summarized in Table- 4 . The thermodynamic parameters $\left(\Delta \mathrm{G}^{\circ}, \Delta \mathrm{H}^{\circ}\right.$, and $\left.\Delta \mathrm{S}^{\circ}\right)$ were calculated to predict the nature of adsorption. Negative values of $\Delta \mathrm{G}^{\circ}(-3.105,-2.045,-0.985 \mathrm{~kJ} / \mathrm{mol})$ at different temperatures $(293,303$, and $313 \mathrm{~K})$ indicate the spontaneity of the process. The increase of $\left(\Delta \mathrm{G}^{\circ}\right)$ with increasing of temperature indicating that adsorption of phosphate ions is higher favorable at a lower temperature condition ${ }^{27}$. The negative value of $\Delta \mathrm{H}^{\circ}(-34.163 \mathrm{~kJ} / \mathrm{mol})$ indicated that the adsorption process of phosphate onto Amberlite IRA-67 is exothermic, which also explain the decreasing of the adsorbed amount of phosphate with temperature increasing. The fact that the reaction of phosphate adsorption is exothermic means that high phosphate removal rate is expected to be obtained at room temperature, and the energy consumed to heat up can be saved, which favors the industrial application of Amberlite IRA-67 in phosphate removal ${ }^{20}$.

Table-4:Thermodynamic Parameters of Phosphate Adsorption

\begin{tabular}{c|c|c|c|c}
\hline$\Delta \mathrm{H}^{\circ}(\mathrm{kJ} / \mathrm{mole})$ & $\Delta \mathrm{S}^{\circ}(\mathrm{kJ} / \mathrm{mole} . \mathrm{K})$ & \multicolumn{3}{|c}{$\Delta \mathrm{G}^{\circ}(\mathrm{kJ} / \mathrm{mole})$} \\
\cline { 3 - 5 } & & $293 \mathrm{~K}$ & $303 \mathrm{~K}$ & $313 \mathrm{~K}$ \\
\hline-34.163 & -0.106 & -3.105 & -2.045 & -0.985 \\
\hline
\end{tabular}

\section{CONCLUSION}

In this study, phosphate ions removal by a weakly basic anion exchanger Amberlite IRA-67 was investigated. The adsorption kinetics is well described by the pseudo-second-order model and the adsorption isotherms follow the Freundlich model. The amberlite IRA-67 resin is very effective for phosphate ions removal from polluted water at $\mathrm{pH}$ range between 2 and 7 with a maximum uptake capacity of $120.63 \mathrm{mg} / \mathrm{g}$. The thermodynamic study revealed that the adsorption is spontaneous and exothermic, the experimental data gave very satisfying results regarding phosphate removal by Amberlite IRA-67 resin with adsorption capacity relatively higher than other support used for the same purpose.

\section{ACKNOWLEDGMENT}

Authors are grateful for the technical help they received from the administration of Sonacome (CPG), and from the exact sciences department.

\section{REFERENCES}

1. Journal Officiel De La RepubliqueAlgerienne $N^{\circ}$ 26, 23 avril 2006, 24 Rabie El Aouel 1427.

2. A.O. Fadiran, S.C. Dlamini, A. Mavuso, Bull. Chem. Soc. Ethiop. 22, 197 (2008), DOI: 10.4314/bcse.v22i2.61286

3. H. Siwek, A. Bartkowiak, M. Włodarczyk, K. Sobecka, Water Air Soil Pollut., 227, 427(2016), DOI:10.1007/s11270-016-3128-0

4. W. Zeng,A. Wang,J. Zhang,L. Zhang,Y. Peng, Chemical Engineering Journal, 296, 234 (2016), DOI: 10.1016/j.cej.2016.03.063

5. J. Rodier, L'analyse de L'eau, Eaux Naturelles, Eaux Résiduaires Et Eau De Mer, $9^{\mathrm{ème}}$ Edition, Dunod, Paris, pp. 337-338.

6. A. M. Aljeboree, A. N. Alshirifi, A. F. Alkaim, Arabian Journal of Chemistry,10, S3381 (2017), DOI: https://doi.org/10.1016/j.arabjc.2014.01.020 
RASĀYAN J. Chem.

Vol. 11 | No. 3 |1126 - 1132 | July - September | 2018

7. I. Langmuir, J. Am. Chem. Soc, 40, 1361 (1916), DOI:10.1021/ja02242a004

8. MM. Yashim, EL. Marjohan, J. Eng. Appl. Sci,11, 11907 (2016), DOI: 10.1515/zpch-1907-5723

9. HMF. Freundlich,Z. Phys. Chem, 57, 385 (1906), DOI: 10.1515/zpch-1907-5723

10. S.Lagergren,K. Sven, Vetenskapsakad Hand, 24,1(1899), DOI: 10.1007/bf01501332

11. YS. Ho, G. Mckay, Process Biochemistry, 34, 451(1999), DOI: 10.1016/s0032-9592(98)00112-5

12. H.L. Yadav, A.Jamal, Rasayan J. Chem., 10(3),1062 (2017), DOI: 10.7324/RJC.2017.1031775

13. D. Shubo, Y. Qiang, H. Jun, Y. Gang, Water Res, 44, 5188 (2010),DOI: 10.1016/j.watres.2010.06.038

14. Y. Ying, G. Bin, I. Mandu, R.Z. Andrew, C. Xinde, P. Pratap, Y. Liuyan, J Hazard Mater, 190, 501 (2011), DOI : 10.1016/j.jhazmat.2011.03.083

15. S. Xiuling, D. Huipu, L. Shijun, Q. Hui,Journal of Chemistry, 2014, 5(2014), DOI: 10.1155/2014/407146

16. H. Li, Z. Ye, Y. Lin, F. Wang, Water Science and Technology, 65 (12), 2091 (2012), DOI:10.2166/wst.2012.121

17. T. Nur, P. Loganathan, J. Kandasamy, S. Vigneswaran,Int J Environ Res Public Health, 13(3),277 (2016), DOI: 10.3390/ijerph13030277

18. Y. Neolaka, E. Kalla, G. Supriyanto, Suyanto,N. Tri Puspaningsih, Rasayan J. Chem.,10(2), 606 (2017), DOI: 10.7324/RJC.2017.1021710

19. B. Salah, A. Moussa, Desalination,275, 231(2011), DOI:10.1016/j.desal.2011.03.004

20. Y. Xiaoli, X. Wentang, A. Juan, Y. Jianguo, Z. Xuejiao, Y. Wenqiang, J Chem, 2015,8(2015), DOI: $10.1155 / 2015 / 853105$

21. ZL. Shi, FM. Liu, SH. Yao, New Carbon Mater,26(4), 299 (2011), DOI: 10.1016/s18725805(11)60083-8

22. K. Xu,T. Deng,J. Liu,W. Peng,Fuel, 89(12), 3668 (2010), DOI: 10.1016/j.fuel.2010.07.034

23. H. Weiwei, W. Shaobin, Z. Zhonghua, L. Li, Y. Xiangdong, R. Victor, H. Fouad, J Hazard Mater, 158(1), 35 (2008), DOI: 10.1016/j.jhazmat.2008.01.061

24. S. Xiaoyan, P. Yanqiu, W. Quyin, C. Zihong, M. Wei, Desalination,280(1-3), 384(2011), DOI: 10.1016/j.desal.2011.07.028

25. K.W. Jung, M.J. Hwang, K.H. Ahn, Y.S. Ok, Int. J. Environ. Sci. Technol,12(10), 3363 (2015), DOI: 10.1007/s13762-015-0766-5

26. E. Akbar, S. Kensuke, B. Yoshiyuki, O. Masazumi, A. Shigeo, Materials Transactions,47(7), 1832 (2006), DOI: 10.2320/matertrans.47.1832

27. A.B Neolaka , E.B.S Kalla , G.A. Malelak , N.K. Rukman , G.Supriyanto, N.N. Tri Puspaningsih, Rasayan J. Chem., 11(2), 494 (2018), DOI: 10.31788/RJC.2018.1121994

[RJC-2081/2018] 